\title{
IAMJ
}

INTERNATIONAL

AYURVEDIC

MEDICAL JOURNAL

(อ) 2 (1)

Research Article

ISSN: 2320-5091

Impact Factor: 6.719

\section{AN OBSERVATIONAL CLINICAL STUDY ON LIPID PROFILE CHANGES BEFORE AND AFTER SHODHNARTH SNEHPAN}

\author{
$\underline{\text { Anupriya Varma }}^{1}, \underline{\text { Ashish Varma }}^{2}$
}

${ }^{1}$ Consultant, Department of Panchakarma, Janseva Ayurvedic hospital, Surendranagar, Gujarat, India

${ }^{2}$ Assistant professor, Department of Obstetrics and Gynecology, L.G. Hospital, Ahemedabad, Gujarat, India

Corresponding Author: preeya005@gmail.com

\section{https://doi.org/10.46607/iamj05p5062021}

(Published online: September 2021)

Open Access

(C) International Ayurvedic Medical Journal, India 2021

Article Received: 26/08/2021 - Peer Reviewed: 20/09/2021 - Accepted for Publication: 21/09/2021

\section{Check for updates}

\begin{abstract}
Background: Snehan(oleation) has a great role in all Panchakarma procedures. The therapeutic procedure by which greasiness is imparted to the body using different kinds of fat (Ghrita, Tail, Vasa, Majja etc) is called Snehan. Snehpan where fat substances are given in increasing doses by Ayurveda physicians, patients may have a fear that it will increase their cholesterol levels, there is this belief that if you consume ghrita, oil etc, it will increase your cholesterol levels and also increases the risk of heart disease. We conducted lipid profile reports before and after Shodhnarth Snehpan in 10 patients in Janseva Ayurvedic Hospital, Surendranagar, Gujarat, India. Objectives: to observe Lipid Profile changes before and after Shodhanarth Snehpan. Management and Outcome: S. cholesterol, Triglycerides, LDL, VLDL in all 10 patients were decreased. HDL however increased which is good cholesterol. Conclusion: The study requires a large group for more specific data. From this study, we can say Snehpan does not increase S.cholesterol levels.
\end{abstract}

Keywords: Lipid profile changes, Shodhanarth snehpan.

\section{INTRODUCTION}

Aabhyantar snehpan (Internal oleation) has an important role in Utkleshan (Aggravation) of Dosha which is necessary before Shodhan (Purification).
But it is first important to know how our body responds to this Sneh?? Either it is Ghrita or Taila or any other fat substance. 


\section{Digestion in the mouth:}

A few things happen in the mouth that start the process of lipid digestion. Chewing mechanically breaks food into smaller particles and mixes them with saliva. An enzyme called lingual lipase is produced by cells on the tongue and begins some enzymatic digestion of triglycerides, cleaving individual fatty acids from the glycerol backbone.

\section{Lipid digestion in the stomach}

In the stomach, mixing and churning helps to disperse food particles and fat molecules. Cells in the stomach produce another lipase, called gastric lipase. Lingual lipase swallowed with food and saliva also remains active in the stomach. But together, these two lipases play only a minor role in fat digestion, and most enzymatic digestion happens in the small intestine.

\section{Lipid digestion in the small intestine}

As the stomach contents enter the small intestine, most of the dietary lipids are undigested and clustered in large droplets. Bile, which is made in the liver and stored in the gallbladder, is released into the duodenum, the first section of the small intestine. Bile salts have both a hydrophobic and a hydrophilic side, so they are attracted to both fats and water. This makes them effective emulsifiers, meaning that they break large fat globules into smaller droplets. Emulsification makes lipids more accessible to digestive enzymes by increasing the surface area for them to act.

The pancreas secretes pancreatic lipases into the small intestine to enzymatically digest triglycerides. Triglycerides are broken down into fatty acids, monoglycerides (glycerol backbone with one fatty acid still attached), and some free glycerol. Cholesterol and fat-soluble vitamins do not need to be enzymatically digested.

\section{Lipid absorption from the small intestine}

Next, those products of fat digestion (fatty acids, monoglycerides, glycerol, cholesterol, and fat-soluble vitamins) need to enter into the circulation so that they can be used by cells around the body. Again, bile helps with this process. Bile salts cluster around the products of fat digestion to form structures called micelles, which help the fats get close enough to the microvilli of intestinal cells so that they can be absorbed. The products of fat digestion diffuse across the membrane of the intestinal cells, and bile salts are recycled back to do more work emulsifying fat and forming micelles.

Once inside the intestinal cell, short- and mediumchain fatty acids and glycerol can be directly absorbed into the bloodstream, but larger lipids such as long-chain fatty acids, monoglycerides, fat-soluble vitamins, and cholesterol need help with absorption and transport to the bloodstream. Long-chain fatty acids and monoglycerides reassemble into triglycerides within the intestinal cell, and along with cholesterol and fat-soluble vitamins, are then incorporated into transport vehicles called chylomicrons. Chylomicrons are large structures with a core of triglycerides and cholesterol and an outer membrane made up of phospholipids, interspersed with proteins (called apolipoproteins) and cholesterol. This outer membrane makes them water-soluble so that they can travel in the aqueous environment of the body. Chylomicrons from the small intestine travel first into lymph vessels, which then deliver them to the bloodstream. Now if we talk about classical texts in Ayurveda,

Internal oleation has so many benefits if done according to disease, person and age.

When the Snehapana is carried out as a preliminary procedure during the Shodhana therapy (Vamana and Virechana) it is known as Shodhana Snehapana ${ }^{2}$. As a part of Shodhana procedure, the Snehapana is carried out to facilitate the mobilization of the Dosha from the site of its manifestation to the site of elimination i.e. koshtha. (Bowel movements) In this process, Utklesha state of the dosha is achieved by the Snehapana. It is given early in the morning. According to Koshtha days of Snehpan can be decided between 5 to 7 days.

Aim and Objectives: To observe lipid profile changes before and after giving Shodhanarth Snehpan.

Materials and Methods: Selection of subject: 10 patients who were undergoing Shodhan in our hospital were selected irrespective of age, sex, caste and religion. 
Type of study: It was an open observational clinical study with a single group only.

Inclusion criteria: Patients who are undergoing Shodhnarth snehpan procedure.

Exclusion criteria: Patients who are contraindicated for Shodhanarth Snehpan.

Criteria for assessment: The assessment was done on the objective parameter e.g. Lipid profile changes.

Observations: 10 patients who are being given Shodhanarth snehpan were registered. Their before and after Lipid profile was done in Janseva Ayurvedic Hospital, Surendra Nagar, Gujarat, India. Snehpan was given according to their disease condition and koshtha. And stopped after achieving Samyak snehpan lakshanas.

Changes in S. Cholesterol: Mean s. cholesterol before giving Shodhanarth Snehpan was $180.26 \mathrm{mg} / \mathrm{dl}$, which remarkably decreased after giving Virechan which was $157.9 \mathrm{mg} / \mathrm{dl}$.

Changes in Triglyceride: Mean Triglycerides before giving Shodhanarth Snehpan was $132.78 \mathrm{mg} / \mathrm{dl}$, which decreased after giving Virechan which was $129.2 \mathrm{mg} / \mathrm{dl}$.

Changes in LDL: Mean LDL before giving Shodhanarth Snehpan was $111.42 \mathrm{mg} / \mathrm{dl}$, which decreased after giving Virechan which was 157.9 $\mathrm{mg} / \mathrm{dl}$.

Changes in VLDL: Mean VLDL before giving shodhanarth snehpan was $26.52 \mathrm{mg} / \mathrm{dl}$, which decreased after giving Virechan which was $25.84 \mathrm{mg} / \mathrm{dl}$.

Changes in HDL: Mean HDL before giving Shodhanarth Snehpan was $42.35 \mathrm{mg} / \mathrm{dl}$, which Increased after giving Virechan which was $43.4 \mathrm{mg} / \mathrm{dl}$.

Table 1: Mean lipid profile changes in 10 patients

\begin{tabular}{|l|r|r|}
\hline & MEAN B.T. & MEAN A.T. \\
\hline S.CHOLESTEROL & 180.26 & 157.9 \\
\hline TRIGLYCERIDES & 132.78 & 129.2 \\
\hline LDL & 111.42 & 88.66 \\
\hline VLDL & 26.52 & 25.84 \\
\hline HDL & 42.35 & 43.4 \\
\hline
\end{tabular}

Chart 1: Mean lipid profile changes before and after Shodhanarth Snehpan

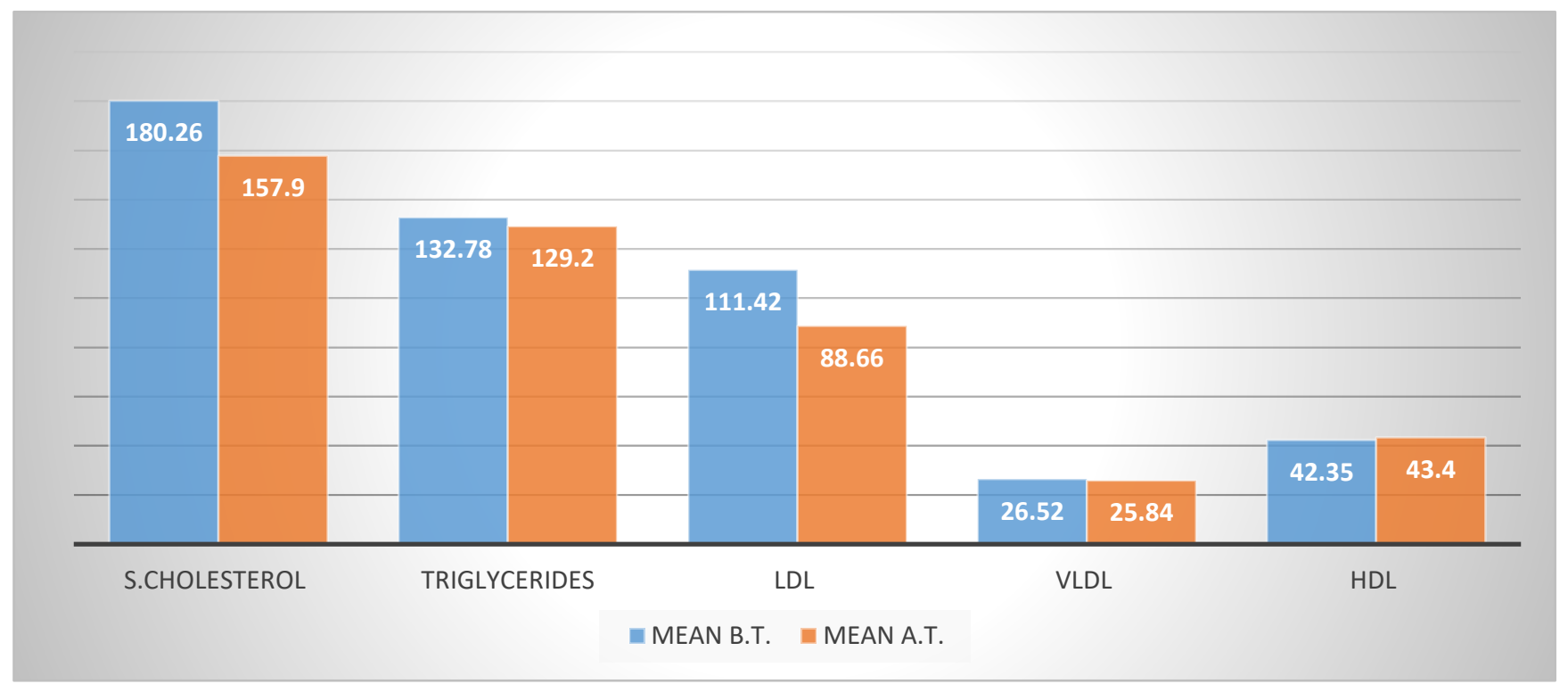




\section{DISCUSSION}

It is a myth that taking Ghrita increases weight and Cholesterol. As we can see in the results, serum cholesterol remarkably decreases after Shodhanarth Snehpan. As we learnt "Sneh bhuyistho shariram", Sneh is essential for the body.

Patil et al. in their study concluded that oral ingestion of lipids does not cause a rise in the level of lipids rather it facilitates in bringing the increased level lipids to normal; even if the lipid levels increase during oral ingestion of lipids (Snehapana) it is transient and comes to normal after purification (Samyaka Shodhana $)^{3}$.

When emetics or purgatives are administered, these increased amounts of the body fluids are evacuated by which the vitiated dosha (humours) and metabolic waste (mala) are also expelled, resulting in the radical cure of the disease. Dr Aparna Bagul concluded in their study that the rise in lipids is transient and comes to normal after Samyaka shodhana. Shodhanartha Snehana is safer if proper Vamana and Sansarjana Krama are performed afterwards and at the end of therapy, there is improvement in the serum lipid levels of patients even after administration of lipids in increasing order ${ }^{4}$.

\section{CONCLUSION}

S. cholesterol, Triglycerides, LDL, VLDL in all 10 patients were deceased. HDL however increased which is good cholesterol. The study can be done in a larger group for better evaluation.

\section{REFERENCES}

1. https://openoregon.pressbooks.pub/nutritionscience/ch apter/5d-digestion-absorption-lipids/

2. Kashinath Shastri and Gorakhnath Chaturvedi, 2001: Charak Samhita of Agnivesha. Revised by Charak and Drudhabala with elaborated 'Vidyotini' Hindi Commentary by, Chaukhamba Bharati Academy, Varanasi, India. Sutra Sthana, 13/61

3. Patil et al, Effect of snehapana (internal oleation) on lipids, A Critical Review, Ancient science of life, 2009;29(2): 32-39.

4. Aparna bagul et al, Effect of Shodhanartha Vardhamana Snehapana on Lipid Profile, WJPMR, 2017;3(5):150-155.

\section{Source of Support: Nil \\ Conflict of Interest: None Declared}

How to cite this URL: Varma Anupriya A \& Varma Ashish J: An Observational Clinical Study On Lipid Profile Changes Before And After Shodhnarth Snehpan. International Ayurvedic Medical Journal \{online\} 2021 \{cited September 2021\} Available from: http://www.iamj.in/posts/images/upload/3086_3089.pdf 